\title{
Gerakan reformis di Tunisia : Studi Pemikiran Khaeruddin Pasya At-Tunisi
}

\section{Hasbiyallah}

Fakultas Ushuluddin, Adab, Dakwah hasbiromli@gmail.com

IAIN Syekh Nurjati Cirebon

\begin{abstract}
Tunisia is one of the most populous Muslim countries in North Africa. This country has a very important role, especially in the spread and development of Islam in Europe because geographically it is very strategically located. The method of this research is historical method that method aimed reconstruction the past suitable with the object that was researched by literature study. In the modern history of Islam in Tunisia, the renewal of Islamic thought was initiated by Khairuddin Pasha, a Russian slave who was bought from a nobleman in Turkey by Bey Ahmad, the ruler of Tunisia at that time. Khairuddin's reformist ideas were seen when he served as highranking official in Tunisi, such as when he was Minister of War, Chairman of the Shura Council, Ambassador to European countries, Chairman of the Finance Commission to Prime Minister of Tunisia
\end{abstract}

Key Words: Thought, Reformation, Tunisia 
Hasbiyallah

Abstrak: Tunisia merupakan salah satu negara yang berpenduduk mayoritas muslim di Afrika Utara. Negara ini memiliki peran yang sangat penting, terutama dalam penyebaran dan pengembangan agama Islam di Eropa karena secara geografis letaknya sangat strategis. Metode penelitian yang digunakan dalam kajian ini adalah metode sejarah, yakni peneliti mengkonstruksi masa lalu dari objek yang diteliti dengan studi kepustakaan. Dalam sejarah Islam moderen di Tunisia, pembaruan pemikiran Islam dirintis oleh Khairuddin Pasya seorang budak Rusia yang setelah dibeli dari seorang bangsawan di Turki oleh Bey Ahmad, penguasa Tunisia masa itu. Gagasan-gagasan reformis Khairuddin terlihat ketiak ia menjabat sebagai pejabat tinggi di Tunisi seperti ketika menjadi Menteri Peperangan, Ketua Majelis Syura, Duta Besar di negara-negara Eropa, Ketua Komisi Keuangan hingga menjadi Perdana Menteri Tunisia.

Kata Kunci: Pemikiran, Reformasi, Tunisia

\section{A. PENDAHULUAN}

Tunisia merupakan salah satu negara yang berpenduduk mayoritas muslim di Afrika Utara. Negara ini memiliki peran yang sangat penting, terutama dalam penyebaran dan pengembangan agama Islam di Eropa karena secara geografis letaknya sangat strategis. Tunisia menjadi penghubung antara negara-negara Timur dengan negara-negara Eropa dan menjadi pintu masuk bagi pengembangan dakwah Islam ke Eropa melalui Spanyol. Pada masa Dinasti Umayah berkuasa, Mu'awiyah telah mengirim 'Uqbah bin Nafi' ke Kairawan di bagian selatan Tunisia untuk melakukan ekspansi, dan setelah berhasil dalam misinya tersebut, ia pun diangkat sebagai Gubernur dan mendirikan kota dan masjid yang diberi nama sesuai dengan namanya dan menjadikan Kairawan sebagai pusat kebudayaan dan peradaban

Tamaddun: Jurnal Sejarah dan Kebudayaan Islam, Volume (9), Issue (2), December 2021 
Hasbiyallah

Islam di Afrika. ${ }^{1}$

Munculnya reformasi dan modernisasi dalam dunia Islam pada awal abad ke-20, bermula dari reaksi terhadap ekspansi dan kejayaan Eropa. Sebenarnya langkah ini dimulai sejak abad ke-18 dan ke-19 oleh sejumlah gerakan Islam, gerakan Islam temasuk juga dalam kategori gerakan sosial. Perubahan suatu peradaban ke peradaban lainnya tidaklah selalu melalui jalan "damai" bahkan sejarah telah membuktikan perubahan perubahan peradaban masyarakat kerap terjadi melalui gerakan-gerakan kolektif atau yang lebih dikenal dengan istilah gerakan sosial sekarang ini. ${ }^{2}$

Dalam sejarah Islam moderen di Tunisia, pembaruan pemikiran Islam dirintis oleh Khairuddin Pasya (1810-1889), seorang budak Rusia yang setelah dibeli dari seorang bangsawan di Turki oleh Bey Ahmad, penguasa Tunisia waktu, itu berubah hidupnya 180 derajat. Sebagaimana telah kita ketahui bahwa kehidupan yang dipenuhi dengan segala kemegahan dan kemewahan istana tidak mungkin diperoleh oleh banyak orang apalagi seorang budak kecuali jika budak tersebut telah dirubah statusnya oleh tuannya. Hal inilah yang terjadi pada Khairuddin di istana Bey di Tunisia di mana pada masa kecilnya, ia tidak hanya diperlakukan seperti anak kandung Bey Ahmad saja, tetapi lebih dari itu, ia juga memperoleh pendidikan yang layak

\footnotetext{
${ }^{1}$ Hasan Ibrahim Hasan, Sejarah dan Kebudayaan Islam, buku kedua, (Kalam Mulia, 2003), cet. ke-1, h. 9.

2 Situmorang, AW. (2013) Gerakan Sosial: Teori dan Praktik. Yogyakarta: Pustaka Pelajar, h 55
}

Tamaddun: Jurnal Sejarah dan Kebudayaan Islam, Volume (9), Issue (2), December 2021 
Hasbiyallah

sebagaimana anak-anak lainnya, bahkan lebih, sehingga berbeda dengan kebanyakan anak-anak muslim di Tunisia pada waktu itu ia berkesempatan memperoleh pendidikan dalam bahasa Prancis dan Turki selain bahasa Arab. ${ }^{3}$

Menurut Azzam S. Tamimi, Khairuddin adalah pemimpin abad ke-19 gerakan reformasi di Tunisia. ${ }^{4}$

Khairuddin juga dijuluki sebagai bapak kebangkitan Tunisia oleh Samir Abu Hamdan. Selain itu Khairuddin juga dijuluki sebagai Bapak Renaisans Pertama. ${ }^{5}$

\section{B. BIOGRAFI KHAIRUDDIN AT-TUNISI}

\section{a. Latar belakang kehidupan Khairuddin At Tunisia}

Khairuddin Pasya adalah seorang budak Rusia yang dibeli oleh Bey Ahmad Pasya penguasa Tunisia masa itu dari seorang bangsawan Turki yang bernama Tahsin Bek. Orangtua Khairuddin tewas dalam pertempuran antara Rusia dengan kerajaan Turki Utsmani sehingga dia hidup tanpa ayah dan ibu.

Sebagai orang yang dekat Bey Ahmad Pasya, Khairuddin sering dipercaya dan ditugaskan dalam pemerintahan oleh Bey Ahmad Pasya. Khairuddin pernah mengurusi masalah korupsi yang

\footnotetext{
3 ibid h. 195.
}

${ }^{4}$ Azzam S Tamimi, "Rise and Fall of Islamic Politcal Thought," The Brunei Times, 10 November, 2008, hal. 3. Azzam S. Tamimi adalah direktur Institut Pemikiran Politik Islam (IIPT), London. Dia menulis dan ceramah tentang isu-isu yang berkaitan dengan pemikiran politik Islam dan politik Timur Tengah.

5 Arnold H. Green, The Tunisian Ulama, 1873-1915: A Social Structure and Response to Ideologicial Currents (New York: Brill Archieve, 1978), hal. 169. Arnold H. Green adalah seorang professor sejarah Universitas Brigham Young Modern yang ahli dalam sejarah Timur Tengah era kolonialisme di Afrika Utara .

Tamaddun: Jurnal Sejarah dan Kebudayaan Islam, Volume (9), Issue (2), December 2021 
Hasbiyallah

dilakukan Ibnu Iyad yang melarikan diri ke Prancis. Selain itu, dia juga mendapat tugas untuk menjual batu-batu mulia dalam rangka mencari dana unutk keperluan perang Cremia tahun 1853. ${ }^{6}$

Kepercayaan yang diberikan Bey Ahmad Pasya kepadanya merupakan ilmu yang tidak ternilai harganya selain membaca buku dan mendapatkan pendidikan formal. Kelak ilmu tersebut menjadi bekalnya melakukan birokrasi dengan pejabat-pejabat kerajaan Turki Utsmani dan perbaikan dalam pemerintahan. Dalam pandangan Mustafa Khaznadar, Khairuddin merupakan seorang pemuda yang mempunyai masa depan yang gemilang sehingga dia menikahkan putrinya dengan Khairudddin. ${ }^{7}$

\section{b. Pendidikan Khairuddin At Tunisia}

Di awal abad ke-13 Tunisia mencapai puncak kejayaannya. Masjid Az Zaitunah di kota Tunis juga merupakan pusat menimba ilmu, selain menjadi tempat untuk beribadah. Di sekitar masjid terdapat universitas dan perpustakaan. Perkembangan ilmu pengetahuan tersebut mendorong berdirinya Universitas AzZaitunah.

Az-Zaitunah merupakan universitas terbesar di Tunisia dan telah eksis menjadi salah satu pusat keilmuan Islam di Afrika Utara. universitas yang sama besarnya dengan Universitas Al-Azhar di Kairo, Mesir. 8

\footnotetext{
${ }^{6}$ Ibid, hal. 198.

${ }^{7}$ Ibid

${ }^{8}$ Hamdan, Samir Abu : Khairuddin At Tunisi: Abu An Nahdah At Tunisiyyah. Misr : Darul Kitab Al 'Alami 1993, h 16
}

Tamaddun: Jurnal Sejarah dan Kebudayaan Islam, Volume (9), Issue (2), December 2021 
Hasbiyallah

Khairuddin belajar di Universitas Az-Zaitunah. Di sini diajarkan Ilmu Tafsir, Hadits, Fiqih, Aqaid, Ilmu Bahasa berupa Nahwu dan Sharaf, Ma'ani, dan Bayan. Selain itu Khairuddin juga belajar Ilmu Syariah dengan cara bergaul dengan para ulama di Tunisia. ${ }^{9}$ Di samping itu, Khairuddin mempelajari sedikit Tauhid, AlQira'ah dan Al-Kitabah serta Al-Quran dan Tajwid. Khairuddin juga mempelajari bahasa Arab, Prancis dan Turki. Pada masa kerajaan Turki Utsmani, Universitas Az- Zaitunah membuka program studi Fisika, Politik Ekonomi, dan Bahasa Prancis. ${ }^{10}$

Selain Khairuddin mendapatkan pendidikan di Universitas Az Zaitunah dia juga mendapatkan pendidikan formalnya di sekolah militer yang di dirikan oleh Ahmad Pasya semasa menjabat sebagai Bey Di Tunisia. ${ }^{11}$ Sekolah tersebut adalah Sekolah Militer Bardo. Sekolah Militer Bardo beroprasi sampai dengan masa pemerintahan Bey Muhammad Tunis. ${ }^{12}$

Sekolah Militer Bardo didirikan untuk mempersiapkan tingkatan-tingkatan dalam ketentaraan dan administrasi. Sekolah ini terbagi menjadi enam sampai sembilan tahun dan intrukturnya langsung dari Perancis. ${ }^{13}$

Khairuddin merupakan sosok yang disiplin dan mempunyai

\footnotetext{
${ }^{9}$ Ibid, h. 25.

${ }^{10}$ Ibid

${ }^{11}$ Nasution, Harun., Pembaharuan Dalam Islam: Sejarah Pemikiran dan Gerakan cet. 7, Jakarta : PT. Bulan Bintang, 1990, h 90.

${ }^{12}$ Strearns, Peter N, and William Leonardo Langer . The Encyclopedia Of Word History : Ancient Medieval, and Modern, Chronologically, Arranged. ed 6. New York : Houghton Mifflin Harcourt, 2001. H 549

${ }^{13}$ Y. G. M. Lulat, A History of African Higher Education From Antiquity to The Present: A Critical Synthesis (Greenwood Publishing Group, 2005), hal. 169.
} 844

Tamaddun: Jurnal Sejarah dan Kebudayaan Islam, Volume (9), Issue (2), December 2021 
Hasbiyallah

kemamuan keras serta cepat dalam menyelesaikan masalah, dan karena pencapaiannya yang luar biasa dalam sekolah militer, Bey Ahmad Pasya mengirim Khairuddin ke Paris, Prancis, untuk melanjutkan pendidikan yang lebih baik. Khairuddin tinggal di Paris, selama empat tahun. Selama masa belajar di Paris dia banyak membaca buku-buku hukum, filsafat, dan politik selain mendalami pengetahuan kemiliteran. Selama tinggal di Prancis, Khairuddin mempelajari bagaimana Prancis menghadapi berbagai masalah. Dia juga mempelajari pemerintahan Prancis dan bertukar pikiran dengan para politikus Prancis. ${ }^{14}$

\section{c. Karir politik Khairuddin At Tunisia}

Kebiasaan berkumpul dengan para intelektual menjadi kelebihan Khairuddin. Dia menjadi orang yang suka melakukan observasi dalam melakukan sesuatu. Karakternya sama dengan karakter Ali Pasya Mubarak, seorang pembaharuan di Mesir. ${ }^{15}$

Dia adalah seorang pemikir yang ingin memperbaharui sesuatu yang dimulai dengan membaca artikel- artikel tentang perubahan peristiwa-peristiwa; peristiwa pemerintahan dan masyarakat. ${ }^{16}$

Sebagaimana mulusnya perjalanan pendidikannya, perjalanan karir Khairuddin juga demikian. Dimulai dengan karirnya di bidang militer setelah menempuh pendidikan secukupnya, hingga di bidang pemerintahan. Dan sejarah mencatat sejumlah prestasi Khairuddin

\footnotetext{
${ }^{14}$ Ibid. hal . 199.

${ }^{15}$ Hamdan, Op. Cit, hal 80

${ }^{16}$ Ibid, hal. 80

Tamaddun: Jurnal Sejarah dan Kebudayaan Islam, Volume (9), Issue (2), December 2021 
Hasbiyallah

dari Menteri Peperangan, Ketua Majelis Syura, Duta Besar di negaranegara Eropa, Ketua Komisi Keuangan hingga Perdana Menteri. ${ }^{17}$

a) Menteri Peperangan

Tahun 1858 Bey Muhamaad Tunis menugerahi Khairuddin pangkat Jenderal ketika itu Khairuddin baru saja kembali Prancis. ${ }^{18}$ dan satu tahun kemudian yaitu pada tahun 1859 Khairuddin diangkat menjadi Menteri Peperangan oleh Bey Muhammad Tunis. ${ }^{19}$

b) Ketua Majelis Syura

Tahun 1863, Khairuddin diangkat menjadi Ketua Majelis Syura atau Majelis Permusyawaratan dengan tetap menjabat sebagai Menteri Peperangan. Saat itu, Khairuddin berusia 53 tahun. Kemudian tahun 1865 Khairuddin berhenti dari Majelis Permusyawaratan atau Majelis Syura. ${ }^{20}$

Anggota-anggota Majelis Syura menginginkan uang wakaf dipergunakan untuk perbaikan angkatan bersenjata yang merujuk pada fatwa seorang ulama Mazhab Maliki, tetapi Khairuddin menolak keinginan tersebut dan memberikan pendapatnya mengenai hal ini.

"Angkatan bersenjata mempunyai anggaran belanja sendiri dalam APBN dan tidak sah untuk mengambil dari uang wakaf kecuali apabila keuangan negara lumpuh dan dipergunakan

${ }^{17}$ A. Mukti Ali, Alam Pikiran Modern Islam di Timur Tengah (Jakarta: Djambatan, 1995) h. 195.

${ }^{18}$ Ibid, h 193.

${ }^{19}$ Ibid

${ }^{20}$ Ibid, $h 210$

Tamaddun: Jurnal Sejarah dan Kebudayaan Islam, Volume (9), Issue (2), December 2021 
untuk pekerjaan-pekerjaan yang adil, tetapi apabila keuangan negara itu dibelanjakan untuk ini dan itu dan dihabiskan untuk kemewahan dan kesenangan, maka tidak sah kita minta bantuan dari harta benda wakaf. ${ }^{21}$

Sebagai ketua Majelis Syura Khairuddin bersikap sangat tegas dalam mengambil keputusan, mempertahankan kebenaran apabila benar, dan tidak memandang seseorang dari harta dan kedudukannya. Selama menjabat sebagai ketua Majelis Syura, Khairuddin sempat membuat kotak aspirasi rakyat yang bertujuan untuk mendengar aspirasi rakyat dan hanya dia yang boleh membuka kotak itu. ${ }^{22}$

c) Ketua Komite Keuangan

Ada tiga hal yang dilakukan Khairuddin selama menjabat sebagai ketua Komite Keuangan, yaitu:23

Pertama, campur tangan negara asing diminimalisasikan bahkan ditiadakan lewat perundingan dengan neggara-negara bersangkutan agar Komite itu hanya mengurusi penggunaan hutanghutang secara terbatas, mengatur APBN dan memberikan jaminan pinjaman beserta bunga pada jangka waktu yang ditetapkan kepada negera-negera kreditor. ${ }^{24}$

Kedua, membangkitkan kepercayaan rakyat terhadap pemerintah dan menggerakkan ekonomi rakyat dengan meringankan

\footnotetext{
${ }^{21} \mathrm{Ibid}$

${ }^{22}$ Ibid h 216

${ }^{23}$ Ibid h, 214

${ }^{24}$ Ibid

Tamaddun: Jurnal Sejarah dan Kebudayaan Islam, Volume (9), Issue (2), December 2021 
Hasbiyallah

pajak pertanian dan menggerakkan penanaman pohon zaitun dan kurma. Bagi setiap orang yang baru menanam zaitun dan kurmadibebaskan pajak selama 20 tahun. ${ }^{25}$

Ketiga, Mustafa Khaznadar yang pada sat itu menjabat Perdana Menteri dicopot jabatannya oleh Komite Keuangan karena terbukti korupsi, maka rakyat yang mengetahui hal ini merasa senang karena orang telah merugikan negara telah dicopot dari jabatannya. ${ }^{26}$

\section{d) Perdana Menteri Tunisia}

Khairuddin menjadi Perdana Menteri selama empat tahun (1873-1877). Dengan diangkatnya Khairuddin sebagai PM, dia dapat melakukan perbaikan dan pembaharuan untuk kepentingan Negara. ${ }^{27}$

Adapun perbaikan-perbaikan yang dilakukan Khairuddin selama menjabat sebagai PM yaitu di bidang politik, hukum, ekonomi, dan pendidikan. Satu persatu perbaikan-perbaikan itu membuat kondisi Tunisia membaik, sehingga orang-orang Eropa merasa khawatir dan takut dengan perkembangan kondisi sosial yang baik dari hari ke hari. Oleh karena itu, Prancis mencari cara untuk menghentikan hal tersebut dengan meminta pemberhentikan Khairuddin dari jabatannya. Pemberhentiannya sebagai PM dipicu oleh ketidaksenangan para pejabat lain yang tidak menginginkan perubahan yang dilakukan Khairuddin selama menjadi PM. ${ }^{28}$

\footnotetext{
${ }^{25}$ Ibid

${ }^{26}$ Ibid

${ }^{27}$ Ibid h 216

${ }^{28}$ Ibid, h 220-222.

Tamaddun: Jurnal Sejarah dan Kebudayaan Islam, Volume (9), Issue (2), December 2021 


\section{a) PEMIKIRAN REFORMIS KHAIRUDDIN PASYA AT TUNISI}

Pemikiran Khairuddin pasya At-Tunisi tertuang pada bukunya yang berjudul Aqwam al-Masalik fi Ma'rifati Ahwal al-Mamalik. Antony Black mengatakan bahwa:

"Khairuddin mengatakan bahwa kajiannya terhadap negaranegara Eropa bertujuan untuk mengambil dari mereka "apa yang cocok untuk syariat kita". Syariat, menurutnya, "dapat diaplikasikan pada persoalan agama maupun urusan dunia". Siapa pun boleh meminjam segala sesuatu dari non- muslim asalkan bisa meningkatkan kemakmuran dan kemaslahatan umat Islam dan itu sama sekali tidak bertentangan dengan syariat. Dengan kata lain, Eropa dapat mengajari kita metode yang dengannya kita bisa mencapai tujuan Syariat" ${ }^{29}$

Dalam melakukan reformasi, Khairuddin menitikberakan pada bidang politik, peradaban, dan ekonomi :

a. Politik

Politik adalah segala aktivitas atau sikap yang berhubungan dengan kekuasaan dan yang bermaksud untuk mempengaruhi, dengan jalan mengubah atau mempertahankan, suatu macam bentuk susunan masyarakat. ${ }^{30}$

Melihat definisi ini, maka hakekat politik menunjukkan perilaku atau tingkah laku manusia, baik berupa kegiatan, aktivitas, ataupun sikap, yang tentunya bertujuan akan mempengaruhi atau mempertahankan tatanan kelompok masyarakat dengan menggunakan kekuasaan. Ini berarti kekuasaan bukanlah hakekat

\footnotetext{
${ }^{29}$ Black, Antony. Pemikiran Politik Islam dari Masa Nabi Hingga Masa Kini. Jakart: Serambi , 2006, h 536

${ }^{30}$ Noer, Deliar. 1983. Pengantar ke Pemikiran Politik. Jakarta : Rajawali. h 6
}

Tamaddun: Jurnal Sejarah dan Kebudayaan Islam, Volume (9), Issue (2), December 2021 
politik, meskipun harus diakui tidak dapat dipisahkan dari politik, justru politik memerlukannya agar suatu kebijaksanaan dapat berjalan dalam kehidupan masyarakat.

Pada umumnya dapat dikatakan bahwa politik adalah bermacam-macam kegiatan dalam suatu sistem politik (atau negara) yang menyangkut proses menentukan tujuan-tujuan dari sistem itu dan melaksanakan tujuan-tujuan itu". 31

Perbedaan-perbedaan dalam definisi tersebut disebabkan setiap sarjana hanya dari satu aspek atau unsur dari politik saja. Unsur tersebut dijadikan pokok-pokok meliputi negara (state), kekuasaan (power), pengambilan keputusan (decisionmaking), kebijaksaan (policy, beleid), dan pembagian (distribution) atau alokasi (allocation). ${ }^{32}$

Tujuan dari pemikiran dan gerakan reformasi adalah terwujudnya masyarakat madani. Sedangkan dalam bidang politik, masyarakat madani merupakan masyarakat yang menghargai hakhak sipil baik individu maupun golonganya. Di dalam kehidupan bernegara, masyarakat yang demikian menuntut adanya transparasi dan proses politik yang demokratis, serta berlakunya check and balances antar berbagai cabang kekuasaan negara, serta terbuka pula terhadap koreksi dan partisipasi masyarakat luas.

Dalam refomasi, proses demokratisasi sangat ditekankan karena hal itu yang menjadi tujuan inti dari refomasi.

Demokrasi yang disimpulkan oleh Khairuddin merupakan

\footnotetext{
${ }^{31}$ Budiardjo, Meriam. 1982. Dasar-Dasar Ilmu Politik. Jakarta : Gramedia. h 8

${ }^{32}$ Ibid h 9
} 
Hasbiyallah

akibat dari sistem politik yang berkembang pada saat itu di Tunisia adalah system kediktatoran. Demokrasi adalah lawan dari kediktatoran. ${ }^{33}$

Secara umum, kekuasaan penguasa dapat dibatasi dengan dua cara yaitu dengan hukum dan konsultasi. Maksud konsultasi tersebut adalah majelis shura atau dewan perwakilan rakyat. Dengan pembatasan kekuasaan penguasa, maka penguasa tidak dapat bertindak sewenang- wenangnya dan korupsi juga tidak akan pernah dilakukan oleh pegawai atau pejabat negara sekalipun. Menurut Lord Acton pemerintahan selalu diselenggrakan oleh manusia dan bahwa pada manusia itu tanpa kecuali melekat banyak kelemahan. Argumentasinya yang terkenal berbunyi, "Power tends to corrupt, but absolute power corrupts absolutely" ${ }^{34}$

Ada dua kelompok di mana penguasa harus berkonsultasi yaitu ulama dan orang-orang yang mempunyai hubungan (politisi). Mereka harus dapat berbicara bebas kepada penguasa, membimbing atau mengarahkan penguasa ke jalan yang benar, dan mencegah penguasa dari perbuatan jahat atau melakukan kejahatan. Dengan begitu ada batasan hukum yang stabil.

Menurut Khairuddin, dua kelompok tersebut dapat juga menghalangi kemajuan umat Islam ketika mereka tidak bergabung dalam pemerintahan. Kelompok pertama, lanjutnya, adalah kelompok ulama di mana mereka mengetahui syariat tetapi tidak mengetahui urusan dunia. Mereka menginginkan penerapan hukum-hukum

\footnotetext{
${ }^{33}$ Ibid h 16

${ }^{34}$ Ibid h 52
} 
Hasbiyallah

agama secara membabi buta, tidak mau memandang apa yang baik dan apa yang sedang terjadi. Sedangkan kelompok kedua adalah kelompok politikus yang mengetahui urusan dunia, tetapi tidak mengetahui agama. Mereka ingin menerapkan tatanan negara-negara Eropa secara menggebu-gebu tanpa merujuk kepada agama.

Ulama adalah pelayan Islam, penjaga tradisi, pemegang ilmu leluhur, dan penganjur moral bagi masyarakat luas. Selain memberikan legitimasi terhadap para penguasa, para ahli hukum juga (ulama) juga menggunakan pengaruh mereka untuk menjegal kebijakan-kebijakan yang tidak adil dan sering kali memimpin atau memberikan legitimasi terhadap pemberontakan melawan kelas penguasa. 35

Kepentingan umum hanya dapat dilayani jika ulama dan umara (politisi) bekerja sama; selain itu, mereka bisa benar-benar melaksanakan syariat, hanya jika mereka mempunyai pengalaman politik. ${ }^{149}$ Oleh karena itu, harus ada penggabungan dua kelompok itu dan satu sama lain saling membantu. Memang ada ajaran-ajaran agama yang wajib diperhatikan, dan ada hal-hal yang diterangkan oleh agama mengenai kemaslahatan umat yang wajib diukur dengan ukuran manfaat dan mudharat, dan semua itu harus dilakukan dengan akal. Namun, ruang gerak ulama sangat dibatasi mengingat Prancis mempunyai andil dan kepentingan dalam pemerintahan Tunisia sehingga partisipasi ulama dalam pemerintahan sangat kecil. Apalagi melihat orientasi para Bey yang condong pada Eropa dan

\footnotetext{
${ }^{35}$ Khaled Abou El-Fadl, Islam dan Tantangan Demokrasi, terj. Gifta Ayu Rahmani dan Ruslani, Jakarta: Ufuk Press, 2004, h 26.
} 
Hasbiyallah

menjadikannya konsuler dalam berbagai permasalahan Tunisia.

Selain itu, ia juga mengatakan bahwa keadilan dan kebebasan merupakan dua tiang yang harus ada dalam suatu negara yang ingin maju. Penduduk Eropa yang mengalami kemajuan, menurut Khairuddin, hal itu terjadi karena adanya keadilan dan kebebasan ini. Itu hukum alam yang tidak akan berubah. Keadilan dan kebebasan pasti akan melahirkan kemakmuran. Kebebasan yang dimaksud Khairuddin di sini meliputi kebebasan pribadi di mana seseorang itu bebas melakukan segala hal untuk kepentingan diri dan pekerjaannya, serta aman dan dilindungi dirinya, kehormatannya, harta bendanya dan persamaan bagi seluruh penduduk dalam hak dan kewajiban, dan kebebasan politik di mana setiap penduduk berhak ikut ambil bagian dalam pemerintahan dan berpartisipasi dalam penetapan undang-undang demi kepentingan bersama antar rakyat dan pemerintah. ${ }^{36}$

\section{b. Hukum}

Dalam masalah hukum, ide moderen Khairuddin terwujud dalam pandangannya tentang perlunya suatu majelis syura yang berwenang menyikapi dan merespon segala permasalahan rakyat dengan sebaik-baiknya sehingga keputusan-keputusan Pemerintah tidak bertentangan dengan kepentingan rakyat. Ia, dalam hal ini mengecam tindakan-tindakan diktatorisme yang dilakukan pemimpin Islam dalam pemerintahannya. Sebagai contoh dalam

${ }^{36}$ Ibid, h 212

Tamaddun: Jurnal Sejarah dan Kebudayaan Islam, Volume (9), Issue (2), December 2021 
Hasbiyallah

penerapan pajak, Khairuddin mengecam tindakan pemerintahnya yang dengan seenaknya saja membelanjakan uang negara di mana jika telah kehabisan uang, maka yang dilakukan adalah dengan menentukan pajak-pajak baru. ${ }^{37}$

Khairuddin menyamakan prinsip shura dengan demokrasi konstisional. Prinsip ini, lanjutnya, sangat mungkin diaplikasikan dalam "urusan politik secara umum" (melalui legislasi parlementer), atau pada "semua kebijakan ekslusif" melalui amanat kementerian; dan dia juga menggambarkan bagaimana prosedur ini dijalankan di Prancis. ${ }^{38}$

c. Ekonomi

Dalam sistem ekonomi, Khairuddin berpihak pada sistem sosialime di mana bagian terbesar kegiatan ekonomi dilakukan masyarakat. Sebagian besar masyarakat Tunisia bermata pencaharian sebagai petani, maka refomasi yang dilakukannya adalah mencari tahu kebutuhan dari para petani tersebut sehingga membangkitkan perekonomian rakyat. Petani sangat ditekan dengan pemberlakuan pajak pertanian. Oleh karena itu, Khairuddin ketika menjadi ketua komite jeuangan Tunisia mengambil kebijakan yang tidak pernah diambil oleh Bey-Bey Tunisia yaitu meringankan bahkan menghapus pajak yang tidak masuk akal untuk ukuran petani. Untuk mengejar ketertinggalan dan menyaingi hasil produksi pertanian dari negara-negara

\footnotetext{
${ }^{37}$ A. Mukti Ali, Alam Pikiran Modern Islam di Timur Tengah (Jakarta: Djambatan, 1995) h. 208

${ }^{38}$ Black, Op.Cit, h. 538.
}

Tamaddun: Jurnal Sejarah dan Kebudayaan Islam, Volume (9), Issue (2), December 2021 
Hasbiyallah

Eropa, Khairuddin melakukan pembinaan kepada para petani dalam pengelolaan lahan pertanian mereka dan pengenalan pada teknologi pertanian modern sehingga mereka tidak lagi menggunakan cara tradisional dalam mengolah lahan dan hasil produksi pertanian mereka.

Menurut Khairuddin, ada dua tiang negara yang bisa menjadi sebab kemunduran dan kemajuan negara. Kedua tiang itu dulu pernah ada di kerajaan Islam. Kedua tiang itu berkembang lalu berangsur-angsur redup dan hilang. Sedangkan kedua tiang itu dahulu tidak terdapat pada kerajaan di Eropa. Kemudian mereka memperbaiki kondisi. Kemajuan yang luar biasa dalam industri, pertanian, perdagangan dan semua itu tidak akan tercapai kecuali dengan keadilan dan kebebasan.

d. Pendidikan

Pendidikan merupakan proses budaya untuk meningkatkan harkat dan martabat manusia, pendidikan selalu berkembang dan akan selalu dihadapkan pada perubahan zaman. Oleh karena itu pendidikan harus dibuat agar sejalan dengan perubahan tersebut, karena jika pendidikan tidak mengikuti irama perubahan zaman maka pendidikan akan ketinggalan dengan lajunya perkembangan zaman itu sendiri.

Berbicara mengenai pendidikan ide-ide pembaharuan Khaeruddin terlihat ketika dia menjadi perdana menteri Tunisia pada tahun 1873 yaitu dengan cara mendirikan Universitas Sadiqi tahun 1875 dengan kurikulum yang modern.

Tamaddun: Jurnal Sejarah dan Kebudayaan Islam, Volume (9), Issue (2), December 2021 
Menurut Khairuddin umat islam harus mempelajari ilmu-ilmu dan ide-ide yang di kembangkan di Barat karena hal tersebut tidak bertentangan dengan Islam.

Dia berpendapat bahwa berpegang teguh kepada agama Islam tidaklah mencegah orang untuk melihat dan mempertimbangkan apa yang terdapat pada bangsa-bangsa lain dan mengambil apa yang baik pada bangsa-bangsa itu dalam hal-hal yang berhubungan dengan kemaslahatan yang bersifat duniawi. ${ }^{39}$

Khairuddin masih melihat ada sebagian ulama tradisional yang melarang atau ragu-ragu terhadap pencapaian intelektual Barat. Dia berusaha keras menjustifikasi ilmu pengetahuan dari pihak asing sebagai ajaran Islam yang baik dan diperlukan untuk meningkatkan keadaan umat Islam kontemporer. Khairuddi mengatakan :

"Mengapa kalian hanya membenci organisasi dan hasil yang diperoleh organisasi itu dan pemerintahan dan pengaturannya, dan keadilan dan cara menegakkannya. Sedang kalian tidak membenci apa yang kalian pergunakan untuk berlomba-lomba dalam pakaian yang indah-indah, alat- alat rumah tangga yang bagus-bagus, dan barang-barang yang baru dan alat- alat untuk kehidupan mewah yang diciptakan oleh negeri Barat? Orang- orang yang membuat senjata-senjata dan menciptakan ilmu dengan pelbagai macam cabangnya. ${ }^{40}$

Menurut Khairuddin kemajuan Eropa dalam ilmu pengetahuan tidak lain karena mereka berusaha mencari penyebab kemuduran sebelumnya. Kemudian mereka bangkit dengan mempelajari ilmu pengetahuain Islam. Orang Barat merupakan tipe

\footnotetext{
${ }^{39}$ Ali, Op. Cit, h 205.

${ }^{40}$ Black, Op. Cit, hal. 535.
} 
Hasbiyallah

orang yang terbuka dengan hal baru, apalagi yang dapat memberikan keuntungan bagi mereka. Menurut Khairuddin mengambil ilmu pengetahuan Barat dan mempelajarinya adalah mengambil sesutu yang pernah dicuri atau diambil mereka dari umat Islam.

Khairuddin tidak memisahkan antara agama dengan ilmu pengetahuan karena dengan agama tidak menjadikan seorang Muslim menghalangi dia untuk mendapatkan hikmah di mana pun dia berada. ${ }^{41}$

\section{b) Kesimpulan}

Khairuddin merupakan salah satu tokoh refromis dari Tunisa ide pembaharuanya ia tuangkan ketika menjabat sebagai pejabat tinggi di Tunisia seperti ketika menjadi Menteri Peperangan Tunisia ia memperbaiki administarasi negara.

Pembaruan Khairuddin juga nampak dalam idenya membentuk Majelis Syura pada 1277 H. Selain itu, pembaruan Khairuddin juga terlihat dalam kebijakannya ketika diserahi tanggungjawab menjadi Ketua Komite Keuangan pada $1286 \mathrm{H}$.

Dalam masalah pemerintahan, ide moderen Khairuddin terwujud dalam pandangannya tentang perlunya suatu majelis syura yang berwenang menyikapi dan merespon segala permasalahan rakyat dengan sebaik-baiknya sehingga keputusan-keputusan Pemerintah tidak bertentangan dengan kepentingan rakyat. Ia, dalam hal ini mengecam tindakan-tindakan diktatorisme yang dilakukan

41

Tamaddun: Jurnal Sejarah dan Kebudayaan Islam, Volume (9), Issue (2), December 2021 
Hasbiyallah

pemimpin Islam dalam pemerintahannya. Sebagai contoh dalam penerapan pajak, Khairuddin mengecam tindakan pemerintahnya yang dengan seenaknya saja membelanjakan uang negara di mana jika telah kehabisan uang, maka yang dilakukan adalah dengan menentukan pajak-pajak baru.

Pembaruan Khairuddin juga terdapat dalam bentuk buku yang berjudul Aqwamul Masâlik fì ma'rifati ahwalil Mamalikmenurtnya pentingnya mencapai kemajuan sebagaimana yang telah dicapai oleh Barat. Dan Jika umat Islam ingin maju seperti negara-negara Barat, mereka tidak perlu merasa bersalah mengambil ilmu Barat untuk meraih kemajuan tersebut karena tidak bertentangan dengan Islam.

\section{Daftar Pustaka}

A. Mukti Ali, Alam Pikiran Modern Islam di Timur Tengah (Jakarta: Djambatan, 1995)

Arnold H. Green, The Tunisian Ulama, 1873-1915: A Social Structure and Response to Ideologicial Currents (New York: Brill Archieve, 1978) Azzam S Tamimi, "Rise and Fall of Islamic Politcal Thought," The Brunei Times, 10 November, 2008

Budiardjo, Meriam. 1982. Dasar-Dasar Ilmu Politik. Jakarta : Gramedia.

Black, Antony. Pemikiran Politik Islam dari Masa Nabi Hingga Masa Kini. Jakart: Serambi , 2006

Hasan Ibrahim Hasan, Sejarah dan Kebudayaan Islam, buku kedua, (Kalam Mulia, 2003), cet. ke-1

Hamdan, Samir Abu : Khairuddin At Tunisi: Abu An Nahdah At Tunisiyyah. Misr : Darul Kitab Al 'Alami 1993

Tamaddun: Jurnal Sejarah dan Kebudayaan Islam, Volume (9), Issue (2), December 2021 
Hasbiyallah

Khaled Abou El-Fadl, Islam dan Tantangan Demokrasi, terj. Gifta Ayu Rahmani dan Ruslani, Jakarta: Ufuk Press, 2004

Nasution, Harun., Pembaharuan Dalam Islam: Sejarah Pemikiran dan Gerakan cet. 7, Jakarta : PT. Bulan Bintang, 1990

Noer, Deliar. 1983. Pengantar ke Pemikiran Politik. Jakarta : Rajawali.

Situmorang, AW. (2013) Gerakan Sosial: Teori dan Praktik. Yogyakarta: Pustaka Pelajar

Strearns, Peter N, and William Leonardo Langer. The Encyclopedia Of Word History : Ancient Medieval, and Modern, Chronologically, Arranged. ed 6. New York : Houghton Mifflin Harcourt, 2001

Y. G. M. Lulat, A History of African Higher Education From Antiquity to The Present: A Critical Synthesis (Greenwood Publishing Group, 2005) 